\title{
HYPOALBUMINEMIA IN MICROSURGICAL FLAPS OF THE MUSCULOSKELETAL APPARATUS
}

\section{A HIPOALBUMINEMIA EM RETALHOS MICROCIRÚRGICOS DO APARELHO MUSCULOESQUELÉTICO}

\author{
ana Carolina Oliveira da Silva ${ }^{1}$ (i), Gustavo Bersani Silva ${ }^{1}$ (i), alvaro Baik Cho ${ }^{1}$ (i), Teng Hsiang Wei ${ }^{1}$ (i), \\ RAMES MATTAR JUNIOR ${ }^{1}$ (1), RAQUEL BERNARDELLI IAMAGUCHI ${ }^{1}$ (i)
}

1. Universidade de São Paulo, Hospital das Clínicas, Medical School, Institute of Orthopedics and Traumatology, Hand and Microsurgery Group, São Paulo, SP, Brazil.

\section{ABSTRACT}

Objective: To evaluate if the levels of serum total protein and serum albumin are risk factors for surgical complications of free flap limb reconstruction. Methods: Consecutive inclusion of all patients undergoing microsurgical flaps for limb reconstruction of complex injuries. We recorded epidemiological and laboratory data, including total proteins and fractions, for descriptive and analytical statistics. Results: Our study analyzed one microsurgical flap from 35 patients that underwent complex injuries of the limbs. In total, 23 patients were men, and mean age of all patients was 35 years. After statistical analysis, no influence of pre or postoperative hypoalbuminemia was observed on the incidence of complications. Patients with hypoalbuminemia had a higher length of stay than those with normal albumin levels $(p=0.008)$. Conclusion: We observed that $71 \%$ of patients had hypoalbuminemia in early postoperative period and we suggest a nutritional support for patients requiring complex traumatic limb reconstruction. Hypoalbuminemia in patients subjected to microsurgical flaps for the treatment of complex traumatic limb injuries did not influence the complications that required surgical reintervention; However, it was associated with prolonged hospital stay. Level of Evidence II, Retrospective study.

Keywords: Free Tissue Flaps. Risk Factors. Hypoalbuminemia. Postoperative Complications.

\section{RESUMO}

Objetivo: Avaliar a influência dos níveis totais de proteína sérica e albumina como fator de risco para complicações de retalhos microcirúrgicos para reconstrução de membros. Métodos: Inclusão consecutiva de todos os pacientes submetidos a retalhos microcirúrgicos para reconstrução de membros de lesões complexas. Foram registrados dados epidemiológicos e laboratoriais, incluindo proteínas e frações totais, para fins estatísticos descritivos e analíticos. Resultados: 35 retalhos microcirúrgicos foram estudados em 35 pacientes com lesões complexas dos membros. A idade média dos pacientes foi de 35 anos, e 23 pacientes eram do sexo masculino. Após análise estatística, não foi observada influência da hipoalbuminemia pré ou pós-operatória na incidência de complicações. Pacientes com hipoalbuminemia permaneceram mais tempo hospitalizados do que aqueles com níveis normais de albumina $(p=0,008)$. Conclusão: Observamos $71 \%$ dos pacientes com hipoalbuminemia no início do período pós-operatório e sugerimos fornecer suporte nutricional para pacientes que necessitam de reconstrução traumática complexa dos membros. A presença de hipoalbuminemia em pacientes submetidos a retalhos microcirúrgicos para o tratamento de lesões traumáticas complexas nos membros não influenciou a presença de complicações que exigiam reintervenção cirúrgica, mas foi associada ao tempo de hospitalização prolongado. Nível de Evidência II, Estudo retrospectivo.

Descritores: Retalhos de Tecido Biológico. Fatores de Risco. Hipoalbuminemia. Complicações Pós-Operatórias.

Citation: Silva ACO, Silva GB, Cho AB, Wei TH, Mattar R Jr, lamaguchi RB. Hypoalbuminemia in microsurgical flaps of the musculoskeletal apparatus. Acta Ortop Bras. [online]. 2020;28(4):168-71. Available from URL: http://www.scielo.br/aob.

\section{INTRODUCTION}

Acute inflammation is the main indicator of tissue infections and lesions, with leukocytosis and extravasation of plasma proteins from extravascular tissue to the site of infection or injury. Pathophysiological responses such as pyrexia, hormone secretion inhibition, and muscle protein depletion are other reactions of the immune system. ${ }^{1}$
Leukocytes and plasma proteins are recruited to the sites of infection and injury, in which they provide immune defense and onset tissue repair. Whereas the concentration of the negative acute phase reactants and albumin reduces, the concentration of plasma proteins entering the inflammatory sites increases, including complement proteins and antibodies. ${ }^{2}$ The posttraumatic hypoalbuminemia is

All authors declare no potential conflict of interest related to this article.

The study was conducted at Universidade de São Paulo, Medical School, Hospital das Clínicas (HCF-MUSP), Institute of Orthopedics and Traumatology, Hand and Microsurgery Group. Correspondence: Raquel Bernardelli lamaguchi. Rua Doutor Ovídio Pires de Campos, 333, São Paulo, SP, Brazil, 05403-010. rbiamaguchi@gmail.com 
questioned not to be an indication of malnutrition but as a biomarker for inflammatory status, ${ }^{3}$ although it is commonly associated with complications and malnutrition in studies for orthopedic surgeries. ${ }^{4}$ Microvascular flap reconstruction technique has evolved, reaching excellent outcomes with a reduced incidence of complications. ${ }^{5}$ However, the treatment of these injuries in traumatic limb reconstruction still presents higher incidences of complications when compared with the treatment for head, neck, and breast. ${ }^{6}$ General risk factors for flap failure are multiple or extensive trauma, smoking, age, and peripheral vascular disease. ${ }^{7}$ Among the perioperative risk factors studied, hypoalbuminemia is a factor that could negatively influence the results of free flap reconstruction. Common causes of free flap failure include arterial and venous thrombosis, infection, anatomic variations, and flap dissection. ${ }^{8}$ In the medical literature, preoperative hypoalbuminemia is identified in poor nutritional conditions and could influence the increase in total flap loss. ${ }^{6,9}$ Studies into the influence of hypoalbuminemia on free flap outcomes have included patients that underwent oncologic reconstruction of the head and neck and breast, in which the patient can have nutritional deficit due to chronic illness, ignoring those subjected to limb reconstruction with microsurgical flaps. Our study sought to evaluate the influence of lower levels of serum total protein and serum albumin in preoperative and postoperative periods in the outcomes of free flap reconstruction of the limbs.

\section{MATERIALS AND METHODS}

This is a prospective, cross-sectional study with predefined data collection, approved by the Ethics Committee (CAAE 42679515.2.0000.0068). We performed a consecutive inclusion of all patients who underwent microsurgical flap reconstruction of limbs, performed at a public university hospital. Patients signed an informed consent form. A monitoring protocol was used with the patient's epidemiological data, pathology-related data and dates of occurrence, as well as clinical follow-up, complication, and end-result data.

The epidemiological data analyzed were sex, age, body mass index (BMI) - in kilograms per square meter $\left(\mathrm{kg} / \mathrm{m}^{2}\right)$, in which obesity was defined when patients achieved a BMI greater than $30 \mathrm{~kg} / \mathrm{m}^{2}$ - and the presence of comorbidities. We recorded Pre-operative and postoperative laboratory data for hemoglobin $(\mathrm{Hb})$ in grams per deciliter $(\mathrm{g} / \mathrm{dL})$, the number of platelets multiplied by $10^{3}$ per cubic milliliter $\left(\times 10^{3} / \mathrm{mm}^{3}\right)$, and levels of serum total protein and serum albumin $(\mathrm{g} / \mathrm{dl})$. The cause of the injury that led to the microsurgical procedure was also recorded.

Perioperative data observed were type of flap in relation to the donor area, type of arterial anastomosis, number of venous anastomoses, and ischemia time of microsurgical flap, defined as the time elapsed between clamping of the vessels at the donor site and releasing of the microvascular clamps of the artery and at least one venous anastomoses, obtaining free flap reperfusion.

We described and included complications following the Clavien-Dindo classification ${ }^{10,11}$ grade III, which requires surgical intervention. Complications were dehiscence, partial or total flap loss, thrombosis with indication of revision of anastomoses, and infection.

\section{Statistical analysis}

The Statistical Package for Social Sciences (SPSS) version 20.0 software was used for analysis with descriptive statistics and the univariate analysis was performed using Pearson Chi-squared test. Fisher's exact test was applied when the expected frequency was less than five. A value of $p$ less than 0.05 was considered statistically significant. For the division of values and analysis, we considered both the presence and absence of comorbidities and hemoglobin values greater than, equal to, or less than $11 \mathrm{~g} / \mathrm{dL}$, according to the World Health Organization ${ }^{12}$ standard anemia definition. Platelets were divided into values greater than, equal to, or less than $450 \times 10^{9} / \mathrm{L}$, according to standardized thrombocytosis values. ${ }^{13}$ Values less than $3.4 \mathrm{~g} / \mathrm{dL}$ were defined as hypoalbuminemia and values less than $6.6 \mathrm{~g} / \mathrm{dL}$ were defined as hypoproteinemia, according to the tests performed in the same clinical laboratory.

\section{RESULTS}

We included 35 microsurgical flaps, one flap from each patient, for complex injuries of the limbs in a one year period, (September 2018 through September 2019). The mean age of the patients was 35 years (SD 14.11). In total, 12 patients were women and 23 were men. Traumatic injuries accounted for $90 \%$ of cases, being motorcycle accident the most common cause of injury, occurring in $55 \%$ of the patients.

The anterolateral thigh (ALT) was the most common type of flap, followed by the latissimus dorsi flap (Figures 1 e 2).

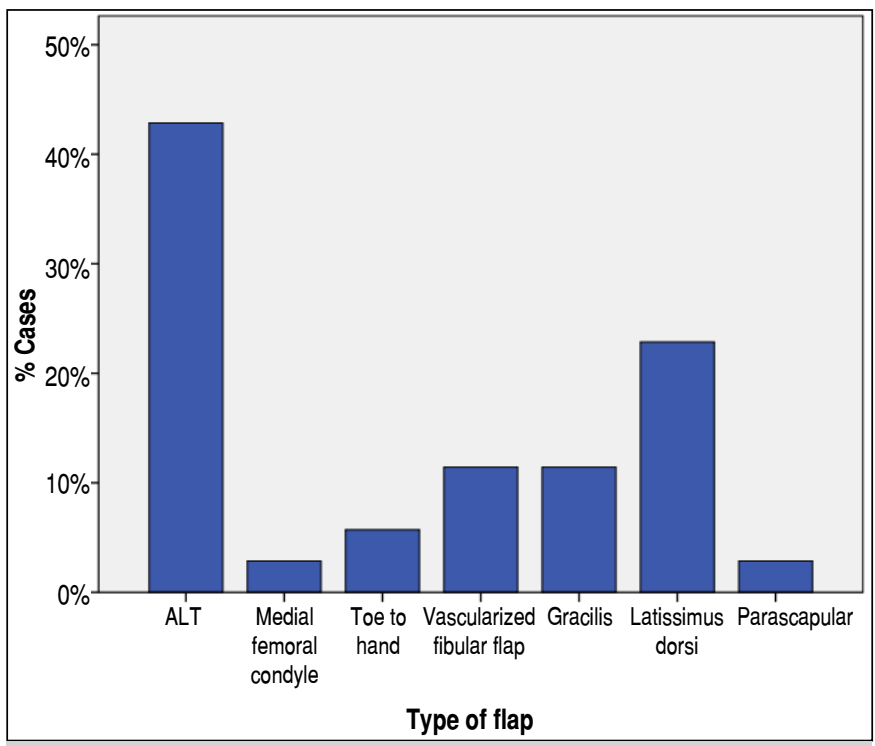

Figure 1. Type of microsurgical flap by donor area. ALT: anterolateral thigh flap.

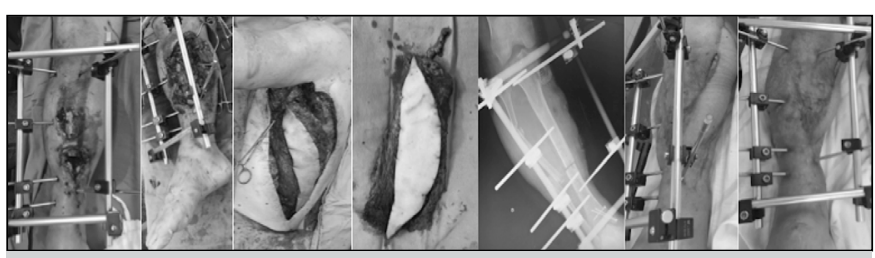

Figure 2. Male, 51 years, motorcycle accident with Gustilo IIIB leg open fracture. Patient referred for orthoplastic treatment after 1 month and subjected to a Latissimus Dorsi free flap for coverage.

Regarding laboratory data, the patients had a mean pre-hemoglobin value of $12.21( \pm 2.08) \mathrm{g} / \mathrm{dL}$. In the postoperative period, the mean hemoglobin value for the group was $10.65( \pm 1.74) \mathrm{g} / \mathrm{dL}$. Eleven patients presented anemia during the preoperative and 12 in the postoperative period.

Analysis of the platelet counts showed that two patients had preoperative thrombocytosis, with a mean value of $326.82 \times 10^{9} / \mathrm{L}$ $\left( \pm 125.58 \times 10^{9}\right)$.

The level of serum total protein in pre-operative period was $6.16 \mathrm{~g} / \mathrm{dL}$ on average $( \pm 1.05)$ and the mean of the level of serum albumin was $3.72( \pm 0.89)$. The mean level of serum total protein in postoperative 
period was $5.43 \mathrm{~g} / \mathrm{dL}( \pm 0.73)$ and the mean level serum albumin was $3.07 \mathrm{~g} / \mathrm{dL}( \pm 0.56)$. Twelve patients had hypoalbuminemia in pre-operative and 25 patients in postoperative period.

Eight patients had complications, five of which required take-back flap due to microvascular thrombosis (total loss of four flaps). There was one case of total flap loss due to infection and one case of dehiscence of the surgical wound. The mean pre - and postoperative hemoglobin values for these eight patients were 12.28 $( \pm 1.58) \mathrm{g} / \mathrm{dL}$ and $10.73( \pm 2.23) \mathrm{g} / \mathrm{dL}$. Preoperative platelets had a mean value of $338.75 \times 10^{3} / \mathrm{mm}^{3}( \pm 0.92)$

The statistical analysis showed no influence of pre- $(p=0.891)$ or postoperative $(p=0.984)$ anemia, thrombocytosis $(p=0.556)$, or hypoalbuminemia $(p=0.115)$ on the incidence of complications of the microsurgical flaps for limb reconstruction.

The mean hospital stay was of 28.60 days for the patients with hypoalbuminemia and 9.80 days for patients without hypoalbuminemia, with a p-value of 0.008 using the Mann-Whitney $U$ test. The microsurgical flap success rate was $86 \%$.

\section{DISCUSSION}

In situations with great physical stress, such as long surgeries for the treatment of complex limb injuries, the serum albumin level decreases, since it is a negative acute phase reactant and the skeletal tissue is the source for restitution of serum albumin level. The intensity of this stress metabolism depends of the extension of trauma, that initiates an acute inflammation in minutes to hours, thus resulting in post-traumatic protein catabolism that can persist for around four months. ${ }^{14}$ A sufficient quantity of proteins is essential for wound healing and immune response; ${ }^{4,15}$ however, the nutritional status of surgical patients is still disregarded, even for oncologic patients. ${ }^{16}$ The nutritional status of surgical patients is an important factor in postoperative complications, including surgical site infection and mortality rates. ${ }^{4}$ Malnutrition is associated with prolonged hospital stay and complications due to surgical stress. ${ }^{17}$ However, studies on the influence of hypoalbuminemia on outcomes and complications of microsurgical flaps for traumatic limb injuries is scarce, being only available for microsurgical flaps for oncologic reconstructions. ${ }^{18}$ In the Hospital das Clínicas da Faculdade de Medicina, the Reconstructive Microsurgery and Hand Surgery Group focusses on the treatment of complex injuries in the Orthopedic Department, which is a reference for trauma. Our population is composed of young adults with normal nutritional status. However, the extensive trauma causes protein depletion such as tumors, similar to the occurring in patients with chronic diseases. Therefore, it is important to study and monitor the nutritional status of these patients after hospitalization. The timing of treatment of complex limb injuries with microsurgical flaps depends on the type of trauma, associated lesions, the referral to the Microsurgery reconstructive Group and the patient's clinical condition. In our study, 34\% of the patients had hypoalbuminemia in pre-operative period, demonstrating that, despite being young adults with a mean age of 35 years, both the severity of the trauma and the delay in referral for definitive microsurgical treatment may lead to a high incidence of malnutrition. We suggest referring to a orthoplastic center for a multidisciplinary treatment at the earliest convenience to avoid protein depletion and complications, as recommended in the literature. ${ }^{19}$ Although serum albumin level is considered to be a long-term marker for nutrition status, ${ }^{6}$ we observed that, after the free flap surgery for limb reconstruction, the percentage of patients with hypoalbuminemia raised to $71 \%$ in early postoperative period. Such increase on protein turnover with a negative whole-body protein balance ${ }^{20}$ suggests the monitoring of the patients and a nutritional support for those requiring limb reconstruction with microsurgical flaps in orthoplastic centers.

Offodile et al. ${ }^{18}$ reported an association between hypoalbuminemia and prolonged hospital stay in patients who underwent free flap treatments. In our study, the patients with hypoalbuminemia had a higher mean length of hospital stay than those with normal albumin levels (28.6 days versus 9.8 days, respectively), with statistical significance $(p=0.008)$. Therefore, hypoalbuminemia is still associated with higher costs due to prolonged Hospital stay caused by healing delay and infection with clinical treatment in patients with traumatic injuries of the limbs, although the serum albumin level is no longer considered a good marker for malnutrition. ${ }^{2}$

Shum et al. ${ }^{6}$ studied patients who underwent reconstruction with microsurgical flaps of the head and neck and observed that those either malnourished or with low prealbumin levels had a higher incidence of total flap loss. A study by Wang et al. ${ }^{21}$ observed that, in radial free forearm flaps, low postoperative concentration of albumin was a risk factor for complications. In our study, hypoalbuminemia in preoperative or post-operative periods was not associated with higher incidence of complications Clavien-Dindo grade III or total flap loss, being the first study of microsurgical flaps for traumatic limb reconstruction not related with oncologic resection and flap reconstruction.

The limitation of our study is the sample size, making it impossible to lead to definitive conclusions. This is a preliminary study and requires further research with continuity of prospective data capture.

\section{CONCLUSION}

Hypoalbuminemia in patients subjected to microsurgical flaps for the treatment of complex traumatic limb injuries did not influence the occurrence of complications that required surgical reintervention; however, it was associated with prolonged hospital stay.

AUTHORS' CONTRIBUTIONS: Each author contributed individually and significantly to the development of this article. ACOS: wrote the paper and edited the manuscript; GBS: performed the surgeries and supervision; ABC: performed the surgeries and supervision; THW: performed the surgeries and supervision; RMJ: supervision; RBI: wrote the paper, edited the manuscript, performed the surgeries and supervision.

\section{REFERENCES}

1. Johnson RW. Inhibition of growth by pro-inflammatory cytokines: an integrated view. J Anim Sci. 1997;75(5):1244-55.

2. Gillis C, Carli F. Promoting perioperative metabolic and nutritional care. Anesthesiology. 2015;123(6):1455-72.

3. Gabay C, Kushner I. Acute-phase proteins and other systemic responses to inflammation. N Engl J Med. 1999;340(6):448-54

4. Lizaur-Utrilla A, Gonzalez-Navarro B, Vizcaya-Moreno MF, Lopes-Prats FA. Altered seric levels of albumin, sodium and parathyroid hormone may predict early mortality following hip fracture surgery in elderly. Int Orthop. 2019;43(12):2825-9.
5. Ninkovic M, Voigt S, Dornseifer U, Lorenz S, Ninkovic M. Microsurgical advances in extremity salvage. Clin Plast Surg. 2012;39(4):491-505.

6. Shum J, Markiewicz MR, Park E, Bui T, Lubek J, Bell RB, et al. Low prealbumin level is a risk factor for microvascular free flap failure. J Oral Maxillofac Surg. 2014;72(1):169-77.

7. Namdar T, Bartscher T, Stollwerck PL, Mailänder P, Lange T. Complete free flap loss due to extensive hemodilution. Microsurgery. 2010;30(3):214-7

8. 8. Wei FC, Demirkan F, Chen HC, Chuang DC, Chen SH, Lin CH, et al. The outcome of failed free flaps in head and neck and extremity reconstruction: what is next in the reconstructive ladder? Plast Reconstr Surg. 2001;108(5):1154-60. 
9. Khuri SF, Daley J, Henderson W, Hur K, Gibbs JO, Barbour G, et al. Risk adjustment of the postoperative mortality rate for the comparative assessment of the quality of surgical care: results of the National Veterans Affairs Surgical Risk Study. J Am Coll Surg. 1997;185(4):315-27.

10. Clavien PA, Barkun J, Oliveira ML, Vauthey N, Dindo D, Schulick RD, et al. The Clavien-Dindo classification of surgical complications: five-year experience. Ann Surg. 2009;250(2):187-96.

11. Moreira LF, Pessôa MC, Mattana DS, Schmitz FF, Volkweiss BS, Antoniazzi JL, et al. Cultural adaptation and the Clavien-Dindo surgical complications classification translated to Brazilian Portuguese. Rev Col Bras Cir. 2016;43(3):141-8.

12. World Health Organization. Haemoglobin concentrations for the diagnosis of anaemia and assessment of severity [Internet]. Geneva: World Health Organization; 2011. Available from: http://www.who.int/vmnis/indicators/haemoglobin

13. Harrison CN, Bareford D, Butt N, Campbell P, Conneally E, Drummond M, et al Guideline for investigation and management of adults and children presenting with a thrombocytosis. Br J Haematol. 2010;149(3):352-75.

14. Rittler $P$, Jacobs R, Demmelmair H, Kuppinger D, Braun $S$, Koletzko B, et al. Dynamics of albumin synthesis after major rectal operation. Surgery. 2007;141(5):660-6

15. Stechmiller JK. Understanding the role of nutrition and wound healing. Nutr Clin Pract. 2010;25(1):61-8.
16. Müller-Richter U, Betz C, Hartmann S, Brands RC. Nutrition management for head and neck cancer patients improves clinical outcome and survival. Nutr Res. 2017;48:1-8.

17. Ho JW, Wu AH, Lee MW, Lau SY, Lam PS, Lau WS, et al. Malnutrition risk predicts surgical outcomes in patients undergoing gastrointestinal operations: results of a prospective study. Clin Nutr. 2015;34(4):679-84.

18. Offodile AC, Aherrera A, Guo L. Risk factors associated with prolonged postoperative stay following free tissue transfer: an analysis of 2425 patients from the american college of surgeons national surgical quality improvement program database. Plast Reconstr Surg. 2014;134(6):1323-32.

19. Olesen UK, Pedersen NJ, Eckardt H, Lykke-Meyer L, Bonde CT, Singh UM, et al. The cost of infection in severe open tibial fractures treated with a free flap. Int Orthop. 2017;41(5):1049-55.

20. Schricker T, Wykes L, Eberhart L, Carli F, Meterissian S. Randomized clinical trial of the anabolic effect of hypocaloric parenteral nutrition after abdominal surgery. Br J Surg. 2005;92(8):947-53.

21. Wang C, Fu G, Liu F, Liu L, Cao M. Perioperative risk factors that predict complications of radial forearm free flaps in oral and maxillofacial reconstruction. Br J Oral Maxillofac Surg. 2018;56(6):514-9. 